\title{
Ministry of Education Turkish Overseas Schools as a Factor of Soft Power in Public Diplomacy: A Qualitative Analysis
}

\author{
Munevver Cetin \\ Marmara University, Ataturk Faculty of Education, Istanbul, Turkey \\ E-mail: munevverolcum@gmail.com \\ Bahar Dogan \\ Sehit Eyup Colakoglu Primary School, Istanbul, Turkey \\ E-mail: 04bdogan@gmail.com
}

\begin{abstract}
In this study, to be able to deeply make sense of and to interpret the problems preventing MOE Overseas Turkish Schools to be a factor of soft power in public diplomacy, the opinions of 30 teachers and head masters, chosen with snowball and convenience sampling were referred with the semi-structured interviews. The out coming data were subjected to content analysis. The main themes of this study were determined as the importance of legal and supervisory arrangements about teachers' sufficiency working abroad for Ministry of Education Turkish Overseas Schools as a factor of soft power in public diplomacy, sharing platforms for common educational and cultural projects to be held and sample applications, coordination with Embassies, areas of students of Turkish Schools to be empowered, the content of in-service training, the image of Turkish Schools, supervision and counselling. In aspect of public diplomacy these themes were examined as soft power and suggestions were made.
\end{abstract}

Keywords: Public diplomacy, soft power, MOE Turkish Overseas Schools.

\section{Special Issue of Educational Sciences}

DOI: $10.7176 / J S T R / 6-06-10$

\section{Kamu Diplomasisi Bağlamında Yumuşak Güç Unsuru Olarak Körfez Ülkelerindeki Türk Okulları: Nitel Bir Analiz}

\author{
Bu çalıșma, Marmara Üniversitesi Eğitim Bilimleri Enstitüsü Eğitim Bilimleri Ana Bilim Dalı Eğitim \\ Yönetimi Bilim Dalı 'nda birinci yazarın danışmanlığında, ikinci yazar tarafından tamamlanmış doktora \\ tezinden üretilmiştir
}

\begin{abstract}
Özet
Bu çalışmada MEB Yurt Dışı Türk Okullarının kamu diplomasisinde yumuşak bir güç unsuru olarak aktif rol oynamasını engelleyen sorunlar ve çözüm stratejilerini derinlemesine anlamlandırabilmek ve yorumlamak için kartopu ve kolay ulaşılabilirlik örnekleme yöntemleri ile belirlenen 30 öğretmen ve yöneticinin görüşlerine yarı yapılandırılmış görüşme formu aracılı̆̆ıyla başvurulmuştur. Elde edilen veriler içerik analizine tabi tutulmuştur. Bu araştırma sonucu ortaya çıkan ana temalar; MEB Yurt Dışı Türk Okullarının kamu diplomasisinde yumuşak güç unsuru olarak yurt dışında görevli öğretmenlerin yeterlilikleri, gerçekleştirilecek eğitsel ve kültürel ortak projeler ve örnek uygulamalar için paylaşım platformları, Büyükelçilikler ile koordinasyon, Türk Okulu öğrencilerinin güçlendirilmesi gereken alanlar, hizmetiçi eğitimlerin içeriği, Türk Okulu imajı, denetim, rehberlik, yasal ve yönetsel düzenlemeler olarak belirlenmiştir. $\mathrm{Bu}$ temalar kamu diplomasisi bağlamında yumuşak güç olarak irdelenmiştir ve öneriler sunulmuştur.
\end{abstract}

Anahtar Kelimeler: Kamu diplomasisi, Yumuşak güç, MEB Yurtdışı Türk Okulları.

$\mathbf{1 3 4} \mid \mathrm{P}$ a g e

www.iiste.org 


\section{Giriş}

Devletlerarası diplomatik faaliyetler II. Dünya Savaşı'ndan sonra sivil toplum örgütlerinin ve ulus ötesi şirketlerin güdümünde şekillenmeye başlamıştır. Küresel çapta hızla yayılan bilginin doğru aktarılması devletlerin kamu diplomasisinde kullandıkları araçlarla sağlanmaktadır. Kamu diplomasisi, eğitim, kültür, sanat, ticaret ve sanayi sahalarında etkin girişimlerle devletlerin, politikalarını benimsetme çabalarını kapsamaktadır. İç ve dış kamuoyunu etkileme, ikna etme ve cezbetme faaliyetlerini içeren kamu diplomasisi yumuşak gücünü kullanarak toplumların, ülkeye karşı bakış açısını biçimlendirmektedir. Bu faaliyetler içinde medyanın kullanımı (fillmler, diziler vb.), resmi ziyaretler, uluslararası kongreler, kültürel organizasyonlar, internet ağları (sosyal medya, tanıtım linkleri vb.), toplantılar yer almaktadır. Tüm bu çabalar devletlerin kendi politikalarını tanıtmaya ve kabul ettirmeye yönelik girişimler olarak adlandirilabilir.

Yumuşak güç, markalaşma, kültürel diplomasi ve kamu diplomasisi devletlerin ulusal çıkarlarını geliştirme amacıyla dış politikada faydalandıkları araçlardır (Pamment, 2012; Hayden, 2012, s.6).Bu araçların yaygınlaşmasında bilgi önemli bir yer tutar. Bilgi devriminin ulusal sınırları aşan etkili ağlar ve toplumlar inşa ettiği iddia edilmektedir. Ayrıca ulus ötesi şirketlerin ve sivil toplum aktörlerinin büyük rol oynadıkları çoğunun ulusal sınırları aşan koalisyonlarla vatandaşları etkilemeleri için kendi yumuşak güçlerini yöneteceklerini savunmaktadırlar. McClory (2015)'e göre, yerel ve küresel aktörler arasındaki etkileşim daha hızlı gelişmekte ve ülkeler eskisinden daha çok işbirliğine önem vermektedirler (McClory, 2015). Dijital iletişimin yaygınlaşmasıyla birlikte gücün farklı biçimleri devreye girmektedir. Ulus ötesi iletişim ve ticaretin artışı yumuşak gücü gündeme getirmektedir. Siyasi liderler cazibe, meşruiyet ve güvenilirlik yarışının birer parçası konumundadırlar. Bilgiyi paylaşma yeterliliği cazibenin ve gücün önemli bir kaynağıdır (Nye, 2004, s.66). Kamu diplomasisi gibi yumuşak gücün araçları da istenen davranışların kazanılması amacıyla etkili kaynakları geliştiren "ikna etme”ye dayanmaktadır. Yumuşak güç, aktörlerin çağdaş politik aksiyonları baskı altına alan çoğulcu medya ve fikir yapılarıyla ilgilenme sebeplerine ilişkin bir dizi uygulamalı argümanların resmini çizmektedir (Hayden, 2012, s.6.).

Yumuşak gücün ortak değerlere ve diğer ülkelerin de bu değerlere bağlı olarak sorumluluğuna ve haklılığına dayanan cazibenin altını çizen Nye (2017, s.99), çok taraflı istişarelerin söz konusu değerlerin savunulmasında daha etkili bir yumuşak güç sağlayacağını belirtmiştir (Nye, 2017, s.99). Yumuşak güç kavramı empirik olarak uygulamada hatları net çizilemeyen ve zor bir kavramdır (Fan, 2008). Yumuşak gücün sosyal ilişkilerdeki aktörlerin, kaynakların ve hedeflerin tanımlanması açık değildir. Ayrıca yumuşak gücü üreten aksiyonların soyutlanması bakış açısını pekiştirmek için hem çok geniştir hem de yenilikçiliği ve çok yönlülüğü kavraması açısından da oldukça statiktir (Vial \& Hanoteau, 2019).

Eğitimin bir yumuşak güç aracı olduğu düşünülürse, bir ülkedeki yabancı okulların her iki ülkenin değerlerini tanıyarak, kavrayarak dinlerken anlatarak, iki yönlü iletişim stratejilerini yürüterek sahip olduğu değerleri benimsetmesi kolaylaşacaktır. Kamu diplomasisi yumuşak güç unsuru olarak eğitim aygıtından da faydalandığı ölçüde uluslararası ilişkiler bağlamında kalıcı başarılar elde edilecektir. Gelişmiş ülkeler, diğer ülkelerde aktif rol oynayan eğitim kurumlarından yararlanarak imajlarını oluşturma amacı taşımaktadırlar. İngiltere'nin dünya çapında finanse ettiği ve kamu diplomasisinin bir aracı olan British Council'in resmi sitesinde yumuşak güç, askeri güç olmadan kültür, eğitim, dil ve değerler yoluyla bir ülkenin dostlar edinebilmesi ve insanları etkilemesi olarak tanımlanmaktadır. Kısacası önemli olan insanların bir ülkeden korkması değil, onu sevmesi ve hükümetlerden ziyade kültür, kurumlar ve insanların ürettiklerinin benimsenmesidir (https://www.britishcouncil.org/).

Fransa Hükümeti, kendi kültürü ve dilini benimseterek toplumlar üzerinde olumlu algı inşa etme sürecinde "FrancEducation" markasını desteklemektedir. "FrancEducation" markası kendi millî eğitim programları çerçevesinde, Fransız dilinin ve kültürünün yayılmasını sağlayan yabancı okullara verilir.” Bu markanın verilmesinde en yetkili mercii Fransız Dış İşleri Bakanlığı'dır. Fransız Dış İşleri Bakanlığı başkanlığında, Fransız Milli Eğitim Bakanlığı, Yurt Dışı Fransızca Eğitim Kurumu ve Laik Eğitim Kurumu temsilcileri marka vermeye yetkilidir (https://www.sb.k12.tr/). Söz konusu marka aslında uluslararası akredite sistemini uygulamaya dönük yapılandırılmıştır. Gelişmiş uluslar kendi dillerini, düşüncelerini, kültürlerini ve değerlerini diğer toplumlara benimsetmek hedefi ile eğitim kurumlarından yararlanmayı çok önceden beri profesyonel bir şekilde gerçekleştirmektedirler.

Federal Almanya Cumhuriyeti Goethe-Institut aracılığıyla dünya çapında kültürünü yaygınlaştırmaktadır. Almanca eğitimi verirken aynı zamanda Almanya'nın kültürel, siyasi ve toplumsal yapısına ilişkin bilgiler vermektedir. Kültürler arası diyalog çalışmalarını planlamakta ve ortaklıklar kurulması için çaba

$\mathbf{1 3 5}$ | P a g e

www.iiste.org 
harcamaktadır (https://www.goethe.de).

Konfüçyus Merkezi, bilim, teknoloji ve eğitim alanındaki hedef ülke ile ilişkileri geliştirirken Çin dilinin de yaygınlaşmasını sağlamayı amaçlamaktadır (https://ci.metu.edu.tr/)

Kamu diplomasisi aracılığıyla ülkeler ve toplumlar arasında sempati ve bağlantılar kurmak için eğitim, önemli imkânlar ve firsatlar sunmaktadır. Ülkeler kültürlerini iletirken, dillerini ve eğitim fırsatlarını yabancı toplumlara aktarabilmektedirler. Bu karşılıklı güvene dayanan ilişkinin sonucu olarak ülkeler politikalarını, kamuoylarının sempatisini kazanarak beslemektedirler (Özkan, 2015).

Türk toplumunda ve dış politikada cereyan eden değişimler Türkiye'de olduğu kadar bölgesel ve küresel sistemdeki kırılmalarla tetiklenmiştir. Bölgesel ve küresel sistemde önemli aktörlerden biri olarak Türkiye, bu değişimi etkin bir koordinasyon içinde tecrübe etmektedir. "Türkiye'nin Yeni Hikâyesi” olarak bu değişim hareketi tanımlanabilir. Türkiye'nin iç dinamiklerini ve dış politikadaki birbirini izleyen etkilerini doğuran değişimler, Avrupa'dan Amerika'ya, Orta Doğu'dan Asya'ya geniş bir sahaya yayılmış ve uluslararası ilişkilerden siyaset bilimine ve kültürel çalışmalara varıncaya kadar çeşitli platformlarda Türkiye, yeni bir tartışmanın odağı olmuştur (Kalın, 2011).

Bir ülkenin yumuşak gücüne katkı sağlayan en önemli faktörlerden biri yüksek kalitedeki eğitim sektörüdür. Literatür incelemeleri sonucunda kamu diplomasisi, yumuşak güç, eğitim kavramları genellikle yükseköğretim kurumlarının etkililiği bağlamında araştırılmıştır (Trilokekar, 2010; Polglase, 2013; Büyükgöze, 2016). Uluslararası arenada etkili bir aktör olan ve karar alma mekanizmalarını güçlendiren Türkiye'nin yumuşak gücü olarak MEB Yurtdışı Türk Okullarının kurumsal yapısını tepeden tırnağa yeniden gözden geçirmesi ve alternatif politikalarla dış kamuoylarını etkilemesi kamu diplomasimizin başarısını artıracak en önemli unsurlardan biridir. Kamu diplomasisi alanında eğitim bağlamında Yunus Emre Enstitüleri ve Büyük Öğrenci Değişimi hareketi ile güçlü bir ivme kazanmış olan Türkiye'nin, MEB Yurtdışı Türk Okullarını da bu perspektiften görerek vizyoner kimliğine kavuşturacak stratejik adımlar atması gerekmektedir. Bu araştırmanın temel amacı, Körfez Ülkelerinde yaşayan vatandaşlarımıza ve soydaşlarımıza eğitim hizmeti sunan Milli Eğitim Bakanlığı’na bağlı Yurtdışı Türk Okullarının kamu diplomasisinde yumuşak bir güç unsuru olarak aktif bir biçimde rol oynamasını engelleyen sorunları ortaya çıkarmak ve bu bağlamda çözüm stratejileri üreterek yabancı kamuoyunu etkileme gücüne sahip bir aktör olması için öneriler sunmaktır.

\section{Yöntem}

Bu bölümde araştırmanın modeli, çalışma grubu, veri aracı, veri toplama ve veri analizi süreçlerine ilişkin bilgiler sunulmuştur. Bu araştırmada MEB Yurtdışı Okullarında görev yapan öğretmen, okul yöneticisi, Maarif Vakfı yöneticileri ve MEB Yükseköğretim ve Yurt Dışı Eğitim Genel Müdürlüğü’nde görev yapmakta olan yöneticilerin görüşlerine göre MEB Yurt Dışı Türk Okullarının kamu diplomasisinde yumuşak bir güç unsuru olarak rol oynamasını engelleyen sorunlara ve bu bağlamda çözüm stratejilerine yönelik görüşlerin derinlemesine ortaya çıkarılması, anlamlandırılması ve yorumlanması amacıyla nitel araştırma yöntemlerinden olgu bilim araştırma desenine başvurulmuştur. Olgu bilim araştırmaları bir olguyu daha iyi tanımamıza ve anlamamıza yardımcı olacak sonuçlar sağlarken; örnekler, açıklamalar ve yaşantılar ortaya koyabilir. Olgu bilim deseni farkında olduğumuz ancak derinlemesine ve ayrıntılı bir anlayışa sahip olmadığımız olgulara odaklanmaktadır. Olgular yaşadığımız dünyada olaylar, deneyimler, algılar, yönelimler, kavramlar ve durumlar gibi çeşitli biçimlerde karşımıza çıkabilmektedir (Şimşek ve Yıldırım, 2011, s. 72). İstatiksel analiz ile sonuçların nicel olarak açıklanmadığı çalışmaları kapsayan nitel araştırmalar, ölçek maddeleri olmadan görüşmeleri ve gözlemleri içermektedir. Nitel araştırmalar, nicel araştırmalarda kullanılacak ölçeklere ilişkin bir hipotez kaynağı olarak yapılmaktadırlar (Marczyk, DeMatteo, \& Festinger, 2017, s.17).

\section{1. Çalışma Grubu}

$\mathrm{Bu}$ araştırmada araştırmanın amacına ulaşabilmek için amaçlı örnekleme yöntemlerinden kartopu ve kolay ulaşılabilirlik örnekleme kullanılmıştır. Kartopu örnekleme yöntemi, nitel araştırmalarda sıklıkla başvurulan bir örnekleme yöntemi olarak araştırmaya ilişkin referans kişilerin önerdiği kişilere zincirleme yöntemi ile ulaşarak verileri toplamayı kapsamaktadır (Biernacki ve Waldorf, 1981). Kolay ulaşılabilirlik örnekleme yöntemi, araştırmadan elde edilecek verilerin hızla ve kolaylıkla elde edilmesine yardımcı olmaktadır. Nitel araştırmalarda maliyet açısından elverişlilik sağlayan kolay ulaşılabilirlik örnekleme yöntemi, ulaşılabilirliği kolaylıkla sağlamaktadır (Yıldırım ve Şimşek, 2006, s.113).

$\mathbf{1 3 6} \mid \mathrm{P}$ a g e

WWW.iiste.org 
Çalışma grubunun oluşturan katılımcılar,

- 2017-2018 eğitim-öğretim y1lında Suudi Arabistan, İran, Katar ve Kuveyt’te, eğitim öğretim faaliyetlerini yürütmekte olan Türk Okullarında görev yapan 14 ögretmen,

- 2017-2018 eğitim-öğretim yılında Suudi Arabistan, İran, Katar ve Kuveyt’te, eğitim öğretim faaliyetlerini yürütmekte olan Türk Okullarında görev yapan 6 okul yöneticisi,

- $\quad$ MEB Yükseköğretim ve Yurt Dışı Eğitim Genel Müdürlüğü’nde görev yapan 3 şube müdürü ve 2 daire başkanı,

- Maarif Vakfı'nda görev yapan 1 başkan danışmanı, 2 daire başkanı ve 1 direktör,

- Yunus Emre Enstitüsü’nde görev yapan 1 uzman olmak üzere 30 kişiden oluşmaktadır.

Araştırmanın yürütülebilmesi için MEB Yenilik ve Eğitim Teknolojileri Genel Müdürlüğü’nden izinler alınmıştır.

Çalışma gruplarına ait demografik bilgiler Tablo 1'de açıklanmıştır.

Tablo 1. Çalışma Grubundaki Katılımcılara Ait Demografik Bilgiler (Suudi Arabistan, İran, Katar ve Kuveyt)

\begin{tabular}{|c|c|c|}
\hline Cinsiyet & Kadın: 6 & Erkek: 24 \\
\hline \multirow{2}{*}{ Yaş Aralığ 1} & 20-29 Yaş: & 40-49 Yaş: 11 \\
\hline & 30-39 Yaş: 17 & 50 ve Üstü Yaş: 2 \\
\hline \multirow{2}{*}{ Eğitim Düzeyi } & Ön Lisans: & Yüksek Lisans:9 \\
\hline & Lisans: 21 & Doktora: \\
\hline \multirow{15}{*}{ Lisans Eğitim Alanı } & \multicolumn{2}{|c|}{ Sınıf Öğretmenliği: 6} \\
\hline & \multicolumn{2}{|c|}{ Matematik Öğretmenliği: 3} \\
\hline & \multicolumn{2}{|c|}{ Din Kültürü ve Ahlak Bilgisi Öğretmenliği: 3} \\
\hline & \multicolumn{2}{|c|}{ Okul Öncesi Öğretmenliği: 1} \\
\hline & \multicolumn{2}{|c|}{ Türk Dili ve Edebiyatı Öğretmenliği: 4} \\
\hline & \multicolumn{2}{|c|}{ Tarih Öğretmenliği: 1} \\
\hline & \multicolumn{2}{|c|}{ Rehberlik ve Psikolojik Danışmanlık: 1} \\
\hline & \multicolumn{2}{|c|}{ İngilizce Öğretmenliği: 4} \\
\hline & \multicolumn{2}{|c|}{ Beden Eğitimi Öğretmenliği: 1} \\
\hline & \multicolumn{2}{|c|}{ Kimya Öğretmenliği: 1} \\
\hline & \multicolumn{2}{|c|}{ Fen Bilgisi Öğretmenliği: 1} \\
\hline & \multicolumn{2}{|c|}{ Yunanca Öğretmenliği: 1} \\
\hline & \multicolumn{2}{|c|}{ Türkçe Öğretmenliği: 1} \\
\hline & \multicolumn{2}{|c|}{ İngiliz Dili ve Edebiyatı: 1} \\
\hline & \multicolumn{2}{|l|}{ Mimarlık: 1} \\
\hline \multirow{7}{*}{ Lisansüstü Eğitim Alanı } & \multicolumn{2}{|c|}{ Eğitim Yönetimi ve Denetimi: 3} \\
\hline & \multicolumn{2}{|l|}{ Dil Bilimi: 1} \\
\hline & \multicolumn{2}{|l|}{ Felsefe: 1} \\
\hline & \multicolumn{2}{|c|}{ Fen Bilgisi Öğretmenliği: 1} \\
\hline & \multicolumn{2}{|l|}{ İlahiyat: 1} \\
\hline & \multicolumn{2}{|c|}{ Kamu Yönetimi: 1} \\
\hline & \multicolumn{2}{|l|}{ İşletme: 1} \\
\hline
\end{tabular}


International Journal of Scientific and Technological Research

ISSN 2422-8702 (Online), DOI: 10.7176/JSTR/6-06-10

Special Issue of Educational Sciences, Vol.6, No.6, 2020

\begin{tabular}{|c|c|c|}
\hline \multirow{2}{*}{ Kidem Y1lı } & 1-9 Yil: 2 & 20 ve Üstü Yıl: 9 \\
\hline & 10-19 Y1l: 19 & \\
\hline \multirow{3}{*}{ Yurtdışı Görev Yı11 } & 1 Y1l: 3 & 3 Yil: 4 \\
\hline & 2 Y1l: 5 & 4 Y1l: 4 \\
\hline & & 5 Yil: 6 \\
\hline \multirow{3}{*}{ Görevlendirilen Ülke } & Katar: 3 & Suudi Arabistan: 9 \\
\hline & Kuveyt: 9 & İran:2 \\
\hline & Kırgizistan: 1 & \\
\hline \multirow{4}{*}{ Görevi } & Öğretmen: 14 & Okul Yöneticisi: 6 \\
\hline & Direktör: 1 & Başkan Danışmanlığı: 1 \\
\hline & Daire Başkanı: 4 & Şube Müdürü: 3 \\
\hline & Uzman: 1 & \\
\hline
\end{tabular}

Tablo 1'de görüldüğü üzere çalışma grubunu oluşturan katılımcıların 6'sı (\%20) kadın, 24'ü (\%80) erkek; 17 'si (\%56) 30-39 yaş, 11'si (\%36) 40-49 yaş, 2'si (\%6) 50 ve üstü yaş aralı̆̆ında; 21'i (\%70) lisans, 9'u (\%30) yüksek lisans mezunu; 6’sı (\%20) sınıf öğretmenliği, 3'ü (\%10) matematik öğretmenliği, 3’ü (\%10) din kültürü ve ahlak bilgisi öğretmenliği, 3’ü (\%10) okul öncesi öğretmenliği, 3’ü (\%10) Türk dili ve edebiyatı öğretmenliği, 1'i (\%3) tarih öğretmenliği, 1'i (\%3) rehberlik ve psikolojik danışmanlık, 4'ü (\%13) İngilizce öğretmenliği, 1'ü (\%3) beden eğitimi öğretmenliği, 1'i (\%3) kimya öğretmenliği, 2'si (\%5) 1'i (\%3) fen bilgisi öğretmenliği, 1’i (\%3) Yunanca öğretmenliği, 1'i (\%3) Türkçe öğretmenliği, 1'i (\%3) mimarlık bölüm lisans mezunu; Çalışma grubunu oluşturan katılımcıların 7'si (\%23) lisansüstü eğitim almakla birlikte bunlardan 3'ü (\%40) eğitim yönetimi ve denetimi, 1'i (\%10) dil bilimi, 1'i (\%10) felsefe, 1'i (\%10) fen bilgisi öğretmenliği, 1'i (\%10) ilahiyat, 1'i (\%10) ilahiyat, 1'i (\%10) kamu yönetimi, 1'i (\%10) işletme, bölüm yüksek lisans mezunu olmak üzere; 2'si (\%7) 1-9 kıdem yılı, 63’ü (\%63) 10-19 kıdem yıl1, 9'u (\%30) 20 ve üstü kıdem yılı arasında; katılımcıların yurt dışı görev sürelerine bakıldığında 30 kişiden 22'sinden (\%73) 3'ü (\%14) 1., 2'si (\%23) 2., 4'ü (\%18) 3., 4'ü (\%18) 4., 6’s1 (\%27) 5. yurtdış1 görev yılında, çalışma grubundan 24 (\%80) katılımcı yurt dışı görevde olup katılımcıların 3'ü (\%12) Katar'da, 9'u (\%38) Kuveyt'te, 9'u (\%38) Suudi Arabistan'da, 2'si (\%8) İran'da; 1'i (\%4) İran'da görevlendirilmiş olup; 14'ü (\%47) öğretmen, 1'i (\%3) koordinatör, 4'ü (\%14) daire başkanı, 1’i (3) uzman, 6’s1 (\%20) okul yöneticisi, 1'i (\%3) başkan danışmanı ve 3'ü (\%10) şube müdürüdür.

\subsection{Veri Toplama Aracl}

Araştırmanın amacına uygun verilere ulaşmak için yarı yapılandırılmış görüşme formu kullanılmıştır. Görüşme tekniği, katılımcı görüşlerini ve algılarını açıklamak için uygundur ve daha fazla bilgi ile cevapların açıklık kazanması amacıyla derinlemesine araştırma firsatı verir (Louise Barriball \& While, 1994). Bu amaçla geliştirilen yarı yapılandırılmış soru, ilgili literatür taramasından geçirilerek ve akademisyenlerin ve uygulayıcıların uzmanlık görüşlerine başvurularak yapılandırılmıştır. Yarı yapılandırılmış görüşme formu iki bölümden oluşmaktadır. Birinci bölümde katılımcılara ait demografik bilgiler, ikinci bölümde dokuz açık uçlu soru yer almaktadır. Araştırmanın amacına yönelik açıklayıcı metin görüşme formunda katılımcılara sunulmuştur. Görüşme formundaki sorular gönüllü katılımcıların görüşlerine başvurularak elde edilmiştir ve her bir görüşme süresi 60-90 dakika arasında sürmüştür.

\subsection{Görüşme Soruları}

Körfez Ülkelerinde yaşayan vatandaşlarımıza ve soydaşlarımıza eğitim hizmeti sunan Milli Eğitim Bakanlığı'na bağlı Yurtdışı Türk Okullarının kamu diplomasisinde yumuşak bir güç unsuru olarak aktif bir biçimde rol oynamasını engelleyen sorunları ortaya çıkarmak ve bu bağlamda çözüm stratejileri üreterek yabancı kamuoyunu etkileme gücüne sahip bir aktör olması için öneriler sunmak için katılımcıların görüşlerini belirlemek amacıyla

$\mathbf{1 3 8} \mid \mathrm{P}$ a g e

www.iiste.org 
1. Yurt dışında görev yapan bir öğretmen hangi tür yeterliliklere sahip olmalıdır?

2. Ortak eğitim projeleri hangi kurumlarla gerçekleştirilebilir?

3. Körfez Ülkeleri’ndeki MEB Yurtdışı Türk Okullarında sürdürülen faaliyetlerle ilgili olarak ortak bir paylaşım platformunu ne gibi faydalar sağlar?

4. Türk Büyükelçiliği'nin eğitim ve kültür alanlarında çalışmalar yapması hangi açılardan önemlidir?

5. MEB Yurtdışı Türk Okulu’ndaki öğrencileri hangi alanlarda güçlendirilmelidir?

6. Yurtdışı görevinde bulunan bir öğretmenin kurumlar arası düzeyde mesleki gelişimini pekiştirici hangi uygulamalar gerçekleştirilebilir?

7. MEB Yurtdışı Türk Okulları'nın imajına ilişkin görüşler nelerdir?

8. MEB Yurtdışı Türk Okulları'nın denetim mekanizmalarının işleyişi hakkındaki görüşler nelerdir?

9. Milli Eğitim Bakanlığı ilgili mevzuatlarının (Kanun, KHK, yönetmelik, genelge) MEB Yurt Dış1 Türk Okulları'nın gereksinimlerine uygun olarak uyumlulaştırabilir mi? soruları katılımcılara sorulmuştur.

\subsection{Verilerin Toplanması}

$\mathrm{Bu}$ araştırmada, araştırmacı tarafından geliştirilen yarı yapılandırılmış soru aracılığıyla 30 katılımcıyla görüşme tekniği aracılığıyla iletişim kurularak veriler elde edilmiştir. Görüşme tekniği, çok çeşitli alanlarda kullanılan görüşme tekniği, bir veri toplama stratejisidir. Yarı yapılandırılmış görüşmeler genellikle önceden belirlenmiş açık uçlu sorular ve görüşmeci ile görüşülen kişi arasındaki diyalogla şekillenen soruları kapsamaktadır (DiCicco - Bloom, \& Crabtree, 2006).

\subsection{Verilerin Çözümlenmesi}

Çalışma grubunu oluşturan öğretmen, okul yöneticisi ve Türkiye Maarif Vakf, Yunus Emre Enstitüsü ve MEB Yükseköğretim ve Yurt Dışı Eğitim Genel Müdürlüğü yöneticilerinin kamu diplomasisinde yumuşak güç unsuru olarak MEB Yurtdışı Türk Okullarına ilişkin sorunlar ve çözüm stratejilerine bağlamındaki görüşlerinden elde edilen veriler NVIVO 12 programı ile içerik analizine tabi tutulmuştur. Belirli prosedürleri izleyen bir teknik olarak içerik analizi farklı bakış açıları geliştirirken, araştırmanın belli bir olguya ilişkin anlayışını derinleştirir ve eylemlere yönelik bilgi sunar (Krippendorff, 2004, s.18). Araştırmanın geçerlik ve güvenirlik çalışmaları kapsamında görüşme soruları uzmanların görüşlerine sunulmuş, temaların ve kodların araştırmanın problemlerini temsil edip etmediği ile ilgili olarak uzman görüşüne başvurulmuştur. Geçerlik ve güvenirlik süreci kapsamında farklı veri kaynaklarından verilerin elde edilmesine firsat sağlayan veri üçgenlemesi yönteminden yararlanılmıştır. Nicel araştırmalarda, araştırmanın geçerlik ve güvenirliğinin sağlanması için uygulanan yöntemler, nitel araştırmalar için inandırıcılık kavramının tercih edilerek bununla ilgili stratejiler geliştirilmesi ile açıklanmıştır (Guba \& Lincoln, 1982; Krefting, 1991; Merriam ve Tissdell, s.242). Nitel yöntemle desenlenmiş bu araştırmada da inandırıcılığın sağlanabilmesi amacıyla Guba ve Lincoln (1982) tarafından geliştirilen inanılırlık, aktarılabilirlik, güvenilebilirlik ve onaylanabilirlik stratejilerine başvurulmuştur.

\section{Bulgular}

$\mathrm{Bu}$ bölümde araştırmanın problemine yönelik bulgulara ve yorumlara yer verilmiştir. Araştırmanın soruları çerçevesinde yurt dışında görevli öğretmenlerin yeterlilikleri, gerçekleştirilecek eğitsel ve kültürel ortak projeler, örnek uygulamalar için paylaşım platformları, Büyükelçilikler ile işbirliği, Türk Okulu öğrencilerinin güçlendirilmesi gereken alanları, hizmetiçi eğitimlerin içeriği, Türk Okulu imajı, denetim ve rehberlik ve yasal ve yönetsel düzenlemeler ile ilgili temalar ortaya çıkmıştır.

$\mathbf{1 3 9} \mid \mathrm{P}$ a g e

WWW.iiste.org 
Tablo 2. Araştırmanın Temaları

\begin{tabular}{l}
\hline Ana Temalar \\
\hline Yurt Dışında Görev Yapan Personelin Sahip Olması Gereken Yeterlilik \\
Alanları \\
\hline Proje Ortaklıkları İçin Girişimler \\
\hline Ortak Paylaşım Platformu \\
\hline Büyükelçilik ve Okul İlişkisi \\
\hline Öğrencilerin Güçlendirileceği Alanlar \\
\hline Hizmetiçi Eğitim Çalışmaları \\
\hline Okul İmajının Tasarımı \\
\hline Eğitim Denetim Mekanizmaları \\
\hline Yasal Düzenlemeler
\end{tabular}

Tablo 2'ye göre araştırmanın problemine ilişkin 9 ana tema ve temalar kapsamında alt temalara ve kodlara ulaşılmıştır.

Tablo 3. Yurt Dışında Görev Yapan Personelin Sahip Olması Gereken Yeterlilik Alanlarına İlişkin Görüşler

\begin{tabular}{lll}
\hline Kodlar & N & F \\
\hline Yabancı Dil Yeterliliği & 23 & 25 \\
\hline Liderlik Özellikleri & 18 & 19 \\
\hline Mesleki Yeterlilikler & 3 & 3 \\
\hline Öğretmen İmajı & 7 & 8 \\
\hline Paydaşlarla İletişim & 12 & 13 \\
\hline Sosyal ve Kültürel Yeterlilikler & 9 & 9 \\
\hline Temsil Yeteneği & 11 & 11 \\
\hline Türk Kültürü ve Sanatlarını Tanıtma Yeterliliği & 5 & 5 \\
\hline Uluslararası Bakış Açısı & 6 & 6 \\
\hline Yurt Dışı Göreve Seçilme & 4 & 5 \\
\hline
\end{tabular}

Yurt dışında görev yapan personelin sahip olması gereken yeterlilik alanlarına ilişkin temaya ait "yabancı dil yeterliliği” (n=23), "liderlik özellikleri” $(n=18)$, “mesleki yeterlilikler” $(n=3)$, "öğretmen imaj1” $(n=7)$, "paydaşlarla iletişim" (n=12), "sosyal ve kültürel yeterlilikler" $(n=9)$, "temsil yeteneği” (n=11), "Türk Kültürü ve Sanatlarını tanıtma yeterliliği” (n=5), "uluslararası bakış açısı” (n=6) ve "yurt dışı göreve seçilme" (n=4) kodlarına ayrılmaktadır. Bu kodlarla ilgili öne çıkan metinler katılımcıların görüşlerinden alıntılarak aşağıda yer verilmiştir.

K1: "Kesinlikle yeterlik alanları olmall. Bunların en başında dil geliyor. En önemli ihtiyaç farklı etnik yapılardaki insanlarla tanışmış, sosyalleşmiş olması gerekiyor." (yabancı dil yeterliliği).

K11: "Dilini kültürünü bilmeli. Iletişim becerisi kuvvetli, dışa açılabilen, organizasyon ayarlayabilen, iletişim kurabilen, nerede nasıl giyineceğini konuşacă̆ını bir öğretmen ve idareci olarak bilmeli. ”(liderlik yeterlilikleri).

K5: "Temsil yeteneği olmasl gerekiyor. Eli yüzü düzgün, sosyal ilişkileri iyi olmall. Türkiye'den yeterli, tecrübeli gelmesi gerekir."(temsil yeteneği).

$140 \mid \mathrm{P}$ a g e

www.iiste.org 
Tablo 4. Proje Ortaklıkları İçin Girişimlere İlişkin Görüşler

\begin{tabular}{lll}
\hline Kodlar & N & F \\
\hline Yurt Dışı Kurum ve Kuruluşlarla Yapılacak Proje Ortaklıkları & 17 & 19 \\
\hline Yurt İçi Kurum ve Kuruluşlarla Yapılacak Proje Ortaklıkları & 8 & 9 \\
\hline Projelerin Kapsamı & 24 & 30 \\
\hline Projelerin Uygulanmasındaki Engeller & 5 & 5 \\
\hline
\end{tabular}

Proje ortaklıkları için girişimler teması, "yurt dışı kurum ve kuruluşlarla yapılacak proje ortaklıkları” (n=17), "yurt içi kurum ve kuruluşlarla yapılacak proje ortaklıkları" $(\mathrm{n}=8)$, "projelerin kapsamı" (n=24), "projelerin uygulanmasındaki engeller" $(\mathrm{n}=5)$ kodlarına ayrılmaktadır. $\mathrm{Bu}$ kodlarla ilgili öne çıkan metinler katılımcıların görüşlerinden alıntılarak aşağıda yer verilmiştir.

K1: "Medya-sosyal medya üzerinden de bu faaliyetleri geliştirebiliriz. Toplumumuzu temsil eden etkinliklerimizi oyunlarımızı tanıtabiliriz. Basında haber konusu olacak projeler üretebiliriz. "( yurt dışı kurum ve kuruluşlarla yapılacak proje ortaklıkları).

K21: “Özellikle burada çok fazla Türk kuruluşu yok. Yunus Emre Enstitüsü var, THY gibi kurumlar var. Iletişim içerisinde olunmall. Bizler de YYE de Türkçe ögretiyoruz. Diyalog halinde uygulamalar yapılmalı." (yurt içi kurum ve kuruluşlarla yapılacak proje ortaklıkları).

Tablo 5. Ortak Paylaşım Platformuna İlişkin Görüşler

\begin{tabular}{lll}
\hline Kodlar & N & F \\
\hline İyi Örneklerin Paylaşımı & 18 & 18 \\
\hline Değişim Programları & 7 & 7 \\
\hline Paylaşım Platformunun Tasarımı & 11 & 11 \\
\hline
\end{tabular}

Ortak paylaşım platformu temasına yönelik kodlar, “iyi örneklerin paylaşımı”(n=18), “değişim programları" $(n=7)$, "paylaşım platformunun tasarımı” $(n=11)$ şeklindedir. Bu kodlarla ilgili öne çıkan metinler katılımcıların görüşlerinden alıntılarak aşağıda yer verilmiştir.

K16: “Öncelikle iyi uygulamaların paylaşılması gerekiyor. Davetiyeler, gösterriler özensiz. Bazıları da çok güzel. Yine $x$ okulunun beden eğitimi öğretmeni sadece futbol oynatıyor. Burada oryantirik-yön bulma ögretmeni bulduk. Resmi bir portal olmall. "(iyi örneklerin paylaşımı).

K18: "Yurt dışını temsil amacıyla öğretmenlerin gelip gitmesi gerekiyor. Koordinasyonun sağlanması çok önemli. Öğretmenlerin ve öğrencilerin ufkunun gelişmesi için gelişime açık olmaları için etkili olur. Birbirlerine ilham kaynă̆ı olurlar."( değişim programları).

Tablo 6. Büyükelçilik ve Okul İlişkisine İlişkin Görüşler

\begin{tabular}{llll}
\hline \multirow{2}{*}{ Alt Temalar } & Kodlar & N & F \\
\hline Genel Değerlendirme & İşbirliği isteği & 14 & 14 \\
\cline { 2 - 4 } & Türk Okullarının işleyişi & 2 & 2 \\
\cline { 2 - 4 } $\begin{array}{l}\text { Eğitimin ön plana çıkması } \\
\text { Süreci }\end{array}$ & Komisyonların kurulması- & 4 & 4 \\
\hline & Eğitim Ateşesi/Müşaviri liderliğinde & & 12 \\
\cline { 2 - 4 } & Etkinliklerin kapsamı & 2 & 2 \\
\hline
\end{tabular}

$141 \mid \mathrm{P}$ a g e

www.iiste.org 
International Journal of Scientific and Technological Research

ISSN 2422-8702 (Online), DOI: 10.7176/JSTR/6-06-10

Special Issue of Educational Sciences, Vol.6, No.6, 2020

Büyükelçilik ve okul ilişkin temasına ilişkin olarak "genel değerlendirme” ve "planlama süreci” alt temaları ortaya çıkmıştır. Genel değerlendirme alt teması "işbirliği isteği”" (n=14), "Türk Okullarının işleyişis" (n=2) ve "eğitimin ön plana çıkması" $(\mathrm{n}=4)$ kodlarına ayrılırken planlama süreci alt teması "komisyonların kurulması-eğitim ataşesi/müşaviri liderliğinde" $(\mathrm{n}=12)$ ve "etkinliklerin kapsamı" (n=2) kodları ortaya çıkmıştır. Bu kodlarla ilgili öne çıkan metinler katılımcıların görüşlerinden alıntılarak aşağıda yer verilmiştir.

K18: “Eğitim ve kültür çalışmalarl yeterli değil. Topu Türk Okulunun üzerine atıyorlar. Suudi Arabistan'da müthiş bir Türkçe’ye rağbet var. Bu konuda kapalı bir toplum. Okulda kurslar açılabilir. Çoğu şey üstten gelir. Biz kendi halimizde yapamayız. Bizim böyle bir hamle yapabilmemiz mümkün değil."(genel değerlendirme:işbirliği isteği).

K1: "Yapılması gereken elçiliğin bir komisyon kurması ve gönüllülük esası ile çalışmalarını gerçekleştirmesi gerekir. Komisyonun gündem belirlemesi, elçilikten yetkili birilerinin başkanlık yapması çok önemli. Yıllık veya aylık temalar belirlenebilir. Örneğin Türkiye'de Turizm, Türkiye'de Eğitim, Türkiye ve Kuveyt ilişkileri gibi konu başlıkları olabilir.”(planlama süreci: komisyonların kurulması-eğitim ataşesi/müşaviri liderliğinde).

Tablo 7. Öğrencilerin Güçlendirileceği Alanlara İlişkin Görüşler

\begin{tabular}{|c|c|c|c|}
\hline Alt Temalar & Kodlar & $\mathrm{N}$ & $\mathrm{F}$ \\
\hline \multirow{4}{*}{ Sosyal Alanlar } & Kulüp çalışmaları & 2 & 2 \\
\hline & Bulunduğu ülkenin sosyal yaşamına uyum sağlama & 5 & 5 \\
\hline & Okul-aile ilişkisi & 1 & 1 \\
\hline & Türk toplumunun kaynaşması & 5 & 5 \\
\hline \multirow{2}{*}{ Kültürel Alanlar } & Halk oyunları & 6 & 6 \\
\hline & Türk el sanatları & 2 & 2 \\
\hline \multirow{2}{*}{ Sportif Alanlar } & Fiziksel aktiviteler & 6 & 6 \\
\hline & Milli sporlar & 4 & 4 \\
\hline \multirow{6}{*}{ Akademik Alanlar } & Okuma alışkanlığının kazanılması & 1 & 1 \\
\hline & Ortak derslerin öğretimi & 2 & 2 \\
\hline & Sınırlı akademik kaynak & 2 & 2 \\
\hline & Türkçe'nin öğrenimi & 9 & 9 \\
\hline & Yabancı dilin öğrenimi & 16 & 16 \\
\hline & Yeni müfredat gereksinimi & 4 & 4 \\
\hline \multirow{5}{*}{ Değerler Eğitimi } & Yabancılaşma & 1 & 1 \\
\hline & Milli değerler & 6 & 7 \\
\hline & Örnek kişilerin davet edilmesi & 3 & 3 \\
\hline & Türk örf ve adetleri & 1 & 1 \\
\hline & Türkiye ziyareti & 2 & 2 \\
\hline
\end{tabular}

Öğrencilerin güçlendirileceği alanlar teması "sosyal alanlar”, "kültürel alanlar”, "sportif alanlar”, "akademik alanlar", "değerler eğitimi” alt temalarına ayrılmaktadır. Sosyal alanlar alt teması, "kulüp çalışmaları" $(n=2)$, "bulunduğu ülkenin sosyal yaşamına uyum sağlama” (n=5), "okul-aile ilişkisi” (n=1), Türk toplumunun kaynaşması" ( $\mathrm{n}=5)$; kültürel etkinlikler alt teması, "halk oyunları" $(\mathrm{n}=6)$, Türk el sanatları" $(\mathrm{n}=2)$; sportif alanlar alt temas1, "fiziksel aktiviteler" $(\mathrm{n}=6)$, "milli sporlar" $(\mathrm{n}=4)$; akademik alanlar alt teması, "okuma alışkanlığının kazanılması" (n=1), “ortak derslerin öğretimi” (n=2), "sınırlı akademik kaynak" (n=2), "Türkçe'nin öğrenimi” (n=9), "yabancı dilin öğrenimi” (n=16) ve "yeni müfredat gereksinimi” ( $(n=4)$; değerler eğitimi alt teması, "yabancılaşma" $(n=1)$, "milli değerler" (n=6), "örnek kişilerin davet edilmesi" ( $n=3)$, "Türk örf ve adetleri” $(n=1)$, "Türkiye ziyareti" (n=2) kodlarına 142 | P a g e

www.iiste.org 
International Journal of Scientific and Technological Research

ISSN 2422-8702 (Online), DOI: 10.7176/JSTR/6-06-10

Special Issue of Educational Sciences, Vol.6, No.6, 2020

WWw.iiste.org

ayrılmaktadır. Bu kodlarla ilgili öne çıkan metinler katılımcıların görüşlerinden alıntılanarak aşağıda yer verilmiştir.

K17: "Sosyal kulüpler çok aktif değil. İngilizce tiyatro yapmak istedim ama diğer arkadaşlar öğrencilerin servis problemi olduğunu söylediler. Bir sorun ortaya çıktı."(sosyal alanlar:kulüp çalışmalari).

K26: "Kültürel geleneklerimizi göreneklerimizi ögretmemiz lazım. Folklor bizim kimlik motiflerimizdir. Enstrüman çalma, halk oyunları oynama bunların ögretilmesi önemli."(kültürel alanlar:halk oyunları).

K7: "Beden öğretmeni koskoca okula yetmeye çalışlyor. Imkansızlıklar içinde öğretmenimizin özel bağlantıları sayesinde çocuklar Kuveyt'te derece yaptılar. O zaman anllyoruz ki imkanlar olsa bu çocuklar bu ülkede liderliğe oynuyorlar.”(sportif alanlar:fiziksel aktiviteler).

K12: "Benim gözlemlediğim her ne kadar anne baba olsa da bizim ülkemizden çok uzaklar. Atasözlerimiz, deyimlerimiz bilinmiyor. Çocuk oyunlarımızı bilmiyorlar. Türkçe öğretilmeli."(akademik alanlar:Türkçe'nin öğrenimi).

Tablo 8. Hizmetiçi Eğitim Çalışmalarına İlişkin Görüşler

\begin{tabular}{lll}
\hline Kodlar & N & F \\
\hline Hizmetiçi Eğitimde Bölgesel Konular & 11 & 11 \\
\hline Yurt İçi Eğitim Seminerleri & 3 & 4 \\
\hline Hizmetiçi Eğitimlerin İçeriği & 7 & 7 \\
\hline Hizmetiçi Eğitimlerin Uygulanamaması & 6 & 6 \\
\hline Kurumlararası Hizmetiçi Eğitimler & 4 & 4 \\
\hline Merkezi Hizmetiçi Eğitimler & 3 & 3 \\
\hline Bilgi Paylaşım Toplulukları & 3 & 3 \\
\hline Performans Değerlendirme & 1 & 1 \\
\hline Sürekli Gelişim & 3 & 3 \\
\hline Uyum Sorunları & 2 & 2 \\
\hline Üniversite Okul İşbirliği & 2 & 2 \\
\hline
\end{tabular}

Hizmetiçi eğitim çalışmaları temasına ilişkin "hizmetiçi eğitimde bölgesel konular" (n=11), "yurt içi eğitim seminerleri" ( $(n=3)$, "hizmetiçi eğitimlerin içeriği" $(n=7)$, "hizmetiçi eğitimlerin uygulanamaması" $(n=6)$, "kurumlararası hizmetiçi eğitimler" $(n=4)$, "merkezi hizmetiçi eğitimler" $(n=3)$, "bilgi paylaşım toplulukları" ( $n=3)$, "performans değerlendirme" $(n=3)$, "sürekli gelişim" $(n=1)$, "uyum sorunları" $(n=3)$, "üniversite okul işbirliği" ( $\mathrm{n}=2)$ kodları ortaya çıkmıştır. Bu kodlarla ilgili öne çıkan metinler katılımcıların görüşlerinden alıntılanarak aşağıda yer verilmiştir.

K17: "Arabistan'a geldik buraya geldiğimizde de ekstra bir eğitim verilmedi. Arabistan kültürü tarihi, dili, coğrafyası ile ilgili eğitimlerin buradaki kıdemli arkadaşlarımız tarafindan verilmesi gerekiyor. "(hizmetiçi eğitimde bölgesel konular).

K28: "Mesleki gelişim çalışmalar yapılmıyor. İletişim alanında kesinlikle öğretmen-öğretmen, öğrenciögretmen arasindaki iletişim verilmeli. Buraya gelen arkadaşların oryantasyon eğitimleri almast gerekir."(hizmetiçi eğitimlerin içeriği).

K17: "Mesleki gelişim seminer döneminde ne yaparsak o. Kişisel olarak kendinizi geliştirebilirsiniz. Gelirken aldı̆̆ımız eğitimler çok iyiydi. Bu eğitimlerin alanında uzman, etkili kişiler tarafindan verilmesi gerekiyor."(merkezi hizmetiçi eğitimler).

$\mathbf{1 4 3} \mid \mathrm{P}$ a g e

www.iiste.org 
International Journal of Scientific and Technological Research

ISSN 2422-8702 (Online), DOI: 10.7176/JSTR/6-06-10

Special Issue of Educational Sciences, Vol.6, No.6, 2020

Tablo 9. Okul İmajının Tasarımına İlişkin Görüşler

\begin{tabular}{lll}
\hline Kodlar & N & F \\
\hline Bulunduğu Ülkenin Dilinin Öğretimi & 2 & 2 \\
\hline Diğer Okullarla İşbirliği & 5 & 5 \\
\hline Kaliteli Okul Binaları & 14 & 14 \\
\hline Kültürel Değerler & 5 & 5 \\
\hline Medyanın Kullanılması & 1 & 1 \\
\hline Okul Tanıtım Faaliyetlerinin Yapılması & 2 & 2 \\
\hline Olumlu Okul Veli İlişkisi & 1 & 1 \\
\hline Öğretmenlerin Gelişimi & 5 & 5 \\
\hline Öğretmenlerin Yaşam Koşullarının İyileştirilmesi & 2 & 2 \\
\hline Türkçe’nin Diğer Okullarda Seçmeli Ders Olması & 1 & 1 \\
\hline Türkiye Sempatisi & 9 & 9 \\
\hline
\end{tabular}

Okul imajının tasarımına yönelik temaya ilişkin ortaya çıkan kodlar "bulunduğu ülkenin dilinin öğretimi" $(n=2)$, “diğer okullarla işbirliğgi" $(n=5)$, "kaliteli okul binaları" $(n=14)$, "kültürel değerler” (n=5), "medyanın kullanılması" ( $n=1)$, “okul tanıtım faaliyetlerinin yapılması" $(n=2)$, “olumlu okul veli ilişkisi”" (n=1), “öğretmenlerin gelişimi” ( $(n=5)$, “öğretmenlerin yaşam koşullarının iyileştirilmesi” ( $n=2)$, “Türkçe’nin diğer okullarda seçmeli ders olması" (n=1), "Türkiye sempatisi” ( $n=9)$ şeklindedir. Bu kodlarla ilgili öne çıkan metinler katılımcıların görüşlerinden alıntılanarak aşağıda yer verilmiştir.

K16: "Okulumuzun son derece olumlu bir imajı var. En aktif okullardan bir tanesiyiz. Katar'da neredeyse gitmediğimiz okul kalmad. Mesela Katar Kadınlar Birliği'nin organizasyonuna katıldık. Türk Okulunu Doha'da blmeyen yoktur. Biz bir ekibiz. Dışa dönük amaçlarımız var. Biz temsil için buradayız."(diğer okullarla işbirliği).

K11: "Şimdi bizim okulun fiziki yapısı ĕgitim öğretime hiç uygun değil. Herkes şaşkınlıkla bakıyor. Suudlu bir arkadaşım vardı. Çok şaşırdı okula. Siz zengin bir ülkesiniz nasıl oluyor bu ... diye sordu. Yıllarca boş boş kira ödüyoruz. Verdiğimiz bir kirayla biz iki bina alırdık."(kaliteli okul binaları).

K17: “Arabistana gelince şunu fark ettim dişarda parklarda halkla bir araya geldiğimiz zaman Türk Okulunda çalıştı̆̆ımı söyleyince şaşırıyorlar. Burada Türk Okulu olduğundan haberleri yok. Türk Okulundan ziyade Türk olmamız çok ilgi çekiyor. Geçmiş bağlarımız var. Dizilerimiz izleniyor. Olumlu, güzel bir imajımız var."(Türkiye sempatisi).

Tablo 10. Eğitim Denetim Mekanizmalarına İlişkin Görüşler

\begin{tabular}{lll}
\hline Kodlar & N & F \\
\hline Yerel Makamlarca Denetim Yapılması & 1 & 1 \\
\hline Çok Yönlü Performans Değerlendirme & 9 & 9 \\
\hline Deneyim Paylaşımı & 1 & 1 \\
\hline Eğitim Ataşelerinin Denetim Görevi & 1 & 1 \\
\hline Etkin Denetim Sistemi İhtiyacı & 7 & 8 \\
\hline Merkezden Ziyaretlerin Yapılması & 2 & 2 \\
\hline Mevzuat Boşluğu & 3 & 3 \\
\hline Okul Müdürünün Merkezden Görevlendirilmesi & 2 & 2 \\
\hline Okul Odaklı Denetim & 8 & 8 \\
\hline Rehberlik Desteğinin Verilmesi & 2 & 2 \\
\hline
\end{tabular}

$\mathbf{1 4 4} \mid \mathrm{P}$ a g e

www.iiste.org 
International Journal of Scientific and Technological Research

Eğitim denetim mekanizmalarına ilişkin olarak "yerel makamlarca denetim yapılması” (n=1), "çok yönlü performans değerlendirme" (n=9), "deneyim paylaşımı" $(n=1)$, "eğitim ataşelerinin denetim görevi” (n=1), "etkin denetim sistemi ihtiyacı" (n=7), "merkezden ziyaretlerin yapılması" (n=2), "mevzuat boşluğu” (n=3), "okul müdürünün merkezden görevlendirilmesi” ( $n=2)$, “okul odaklı denetim" (n=8) ve "rehberlik desteğinin verilmesi” ( $\mathrm{n}=2)$ kodları ortaya çıkmıştır. Bu kodlarla ilgili öne çıkan metinler katılımcıların görüşlerinden alıntılanarak aşağıda yer verilmiştir.

K18: “Türk Okullarının denetim mekanizması Türkiye'den çok rahat. Öğretmen kendini hiç geliştirmeden de gidebiliyor. Arapça öğrenenin görevini uzatma gibi ödüller verilebilir. Her yıl görev uzatma belirli kazanımlara bă̆lı olmall. Yaptırım ve mükâfat olmall.”(çok yönlü performans değerlendirme).

K8: "Bakanlıktan yetkili kişilerin gelip hal hatır sorması, artı ve eksilerimizi sorması önemli. Yapıcı olumlu dönüşler oluyor. Tecrübe paylaşımı yanlış algılamaların önüne geçer.”(deneyim paylaşımı).

K15: "Denetim mekanizması amir olarak ataşeler tarafindan sağlanıyor. Bize bir yılda bir kere geldi. Geldiğinde benim sınffima bile gelmedi. Gelsin okulların eksikliklerine baksın. Yetersiz olarak görüyorum. "(etkin denetim sistemi ihtiyacl).

Tablo 11. Yasal Düzenlemelere İlişkin Görüşler

\begin{tabular}{lll}
\hline Kodlar & N & F \\
\hline Bölgesel Çözümlerin Belirlenmesi & 7 & 7 \\
\hline Destekleme ve Yetiştirme Kursları & 2 & 2 \\
\hline E-Okul Yönetim Bilgi Sistemi & 1 & 1 \\
\hline İlgili Yönetmeliklerin Güncellenmesi & 14 & 14 \\
\hline İzin Günlerinin Düzenlenmesi & 13 & 13 \\
\hline Maaşların Birleştirilmesi & 2 & 3 \\
\hline Okul Servislerinin Yasalı̆̆ı & 1 & 1 \\
\hline Oturum Vergisinin Alınması & 3 & 3 \\
\hline Öğretmenlerin Görevlendirilmesi & 1 & 1 \\
\hline Sağlık Ödemelerinin Yapılandırılması & 14 & 15 \\
\hline Ulaşım Giderleri & 1 & 1 \\
\hline
\end{tabular}

Yasal düzenlemeler temasında ortaya çıkan kodlar "bölgesel çözümlerin belirlenmesi” (n=7), "destekleme ve yetiştirme kursları" ( $\mathrm{n}=2)$, "e-okul yönetim bilgi sistemi” $(\mathrm{n}=1)$, "ilgili yönetmeliklerin güncellenmesi" $(n=14)$, “izin günlerinin düzenlenmesi” $(n=13)$, "maaşların birleştirilmesi” $(n=2)$, "okul servislerinin yasallığı” ( $\mathrm{n}=1)$, “oturum vergisinin alınması” $(\mathrm{n}=3)$, “öğretmenlerin görevlendirilmesi” (n=1), "sağlık ödemelerinin yapılandırılması" ( $n=14)$, "ulaşım giderleri” ( $n=1)$ şeklindedir. Bu kodlarla ilgili öne çıkan metinler katılımcıların görüşlerinden alıntılanarak aşağıda yer verilmiştir.

K6: "Her ülkenin farklı özellikleri var. Bir kanun çıkarıp bütün okullara uygulamamız mümkün değil. Mesela standartlar yönetmeliği var yurt içindeki okullar için. Ama bu mesela Afrika'da farkl. Onların müfettişleri var, notlar tutuyorlar. Bir esneklik olmall. ”(bölgesel çözümlerin belirlenmesi).

K20: "Yurt dışında faaliyet gösteren okullarla ilgili bir yönetmelik çalışması yaptık. 2010 yılında Orta Asya'da karşılıklı anlaşmalarla yapılandırılan okullar var, Orta Doğu'da ise özel okul statüsünde okullarımız. Yurt Dışında Faaliyet Gösteren MEB Himayesindeki Türk Okulları Yönetmeliği çıkarılmalı. Mevcut durumlarda boşluklar ve karışıklıklar var.”(ilgili yönetmeliklerin güncellenmesi).

K22: "Bir kere öncelikle tatil konusu olmall. Bizim 30 gün iznimiz olmall 14 günde mazeret iznimiz var. Biz elçilik personeli değiliz. Burada 2 ay ne yapacağız. Düşünüyorum tamam burada her halükarda ölü bir yaşam var yazın bir görevimiz yok. "(izin günlerinin düzenlenmesi). 


\section{Tartışma ve Sonuç}

$\mathrm{Bu}$ bölümde MEB Yurt Dışı Türk Okullarının kamu diplomasisinde yumuşak güç unsuru olarak aktörleşmesinin önündeki engeller ve çözüm stratejilerini belirlemek amaciyla, MEB Yükseköğretim ve Yurt D1şı Eğitim Genel Müdürlüğü yetkililerin, Türk Okullarında görevli öğretmen ve idarecilerinin, Maarif Vakfı çalışanlarının ve Yunus Emre Enstitisü personelinin görüşleri doğrultusunda ulaşılan bulgularla ilişkili olarak sonuç, tartışma ve önerilere yer verilmektedir. Araştırma problemleri kapsamında MEB Yurt Dışı Türk Okullarının kamu diplomasisinde yumuşak güç unsuru olarak yurt dışında görevli öğretmenlerin yeterlilikleri, gerçekleştirilecek eğitsel ve kültürel ortak projeler, örnek uygulamalar için paylaşım platformları, Büyükelçilikler ile işbirliği, Türk Okulu öğrencilerinin güçlendirilmesi gereken alanları, hizmetiçi eğitimlerin içeriği, Türk Okulu imajı, denetim ve rehberlik ve yasal ve yönetsel düzenlemeler ile ilgili temalar ortaya çıkmıştır.

MEB Yurt Dışı Türk Okullarında görevli öğretmen ve idarecilerin sahip olması gereken yeterlilik alanları, yabancı dil yeterliliği (23/30), liderlik özellikleri (18/30), mesleki yeterlilikler (3/30), öğretmen imajı (7/30), paydaşlarla iletişim (12/30), sosyal ve kültürel yeterlilikler (9/30), temsil yeteneği (11/30), Türk Kültürünü ve Sanatlarını tanıtma yeterliliği (5/30), uluslararası bakış açısı (6/30), yurt dışı göreve seçilme (5/30) araştırmaya katılan katılımcılar tarafından vurgulanmıştır. Örgütlerin değişimi toplumsal hayatın değişmesi sonucu kaçınılmazdır. Değişimin gerçekleşebilmesi için çalışanların desteği gerekmektedir. Çalışanların desteğinin ve katılımının sağlanabilmesi için öz yeterlik inançlarının yüksek olması gerekmektedir (İnandı, Yeşil, Karatepe, ve Uzun, 2015). MEB Yurt Dışı Türk Okullarında görevli öğretmen ve idarecilerin yeterlilik alanlarına ilişkin bulgular doğrultusunda öğretmenlerin ve idarecilerin değişime ilişkin öneriler sundukları ortaya çıkmaktadır. Okul idarecilerinin liderlik yeterliliklerinin geliştirilmesine yönelik önlemler alınması öne çıkan öneriler arasındadır. Türk Okullarında görevli öğretmen ve okul yöneticilerinin görev yaptıkları ülkede rahatlıkla iletişim kurabilecekleri düzeyde yabancı dil bilgisi yeterliliğine sahip olunması gerekmektedir. Araştırmanın bulgularından birisi de MEB Yurt Dışı Türk Okullarının ortak eğitim projeleri üretebileceği kurum ve kuruluşlar, yurt dışı kurum ve kuruluşlarla yapılacak proje ortaklıkları (17/30), yurt içi kurum ve kuruluşlarla yapılacak proje ortaklıkları (8/30), projelerin kapsamı (24/30), projelerin uygulanmasındaki engeller (5/30) çalışma grubu tarafından ifade edilmektedir. Projelerin kapsamına ilişkin katılımcıların eğitim ve kültür alanlarında görüşlerini ifade ettikleri görülmektedir. Bu bağlamda ulaşılan bulgulardan birisi de, MEB Yurt Dışı Türk Okullarında gerçekleştirilen projelerin ortaklıklarla desteklenmesidir. Bu kapsamda yurt dışı kurum ve kuruluşlarla yapılacak proje ortaklıklarının uygulanması bulgusuna ulaşılmıştır. Eğitim programları ile dikkat çeken ülkeler, kendilerini birer cazibe merkezi konumuna getirecek yenilikler için araştırmalar yapmaktadırlar. Sonuç olarak ülkeler birbirleri arasında ortak değerler oluşturulması, farklı kültürlerin tanıtılması ve sivil diyaloğun geliştirilmesi, eğitim alanında gerçekleştirilecek işbirlikleri ile önem kazanmaktadır (Ünal Erzen, 2014, s.130). Araştırmadan elde edilen diğer bir bulgu da MEB Yurt Dışı Türk Okullarının ortak paylaşım platformları aracılığıyla etkinlik ve etkililik alanlarının geliştirilmesidir. Körfez Ülkelerindeki MEB Yurt Dışı Türk Okullarında sürdürülen etkinliklerin sergileneceği paylaşım platformuna yönelik katılımcılar, iyi örneklerin paylaşımının gerektiğini (18/30), değişim programlarının gerçekleşmesi gerektiğini (7/30), paylaşım platformunun tasarımının nasıl yapılması gerektiğini (11/30) ifade etmektedirler. Ipe (2003)' e göre, bilgi paylaşımı örgüt içindeki kişilerin diğerleri ile mevcut bilgiyi paylaşma davranışıdır. Bilgi paylaşımı alıcı ve verici arasındaki bilginin benimsenmesi ile sonuçlanacak iki ya da daha fazla kişi arasında gönüllülüğe dayalı, bilinçli bir davranıştır. Bilgi paylaşımını etkileyen temel faktörler, bilginin doğası, paylaşma motivasyonu, paylaşma firsatları ve örgütsel kültürdür (Ipe, 2003). Araştırmadan elde edilen bulgulardan birisi ise, büyükelçilik ve okul ilişkisinin etkin bir biçimde yapılandırılması gerektiğidir. Türk Büyükelçiliklerinin eğitim ve kültür alanlarında çalışmalar yapmasında katılımcıların işbirliği isteğini (14/30), Türk Okullarının işleyişsinin elçilik nezdinde (2/30), eğitimin ön plana çıkarılması gerektiğini (4/30), planlama sürecinde eğitim ataşesinin /müşavirinin liderliğinde komisyonların belirlenmesi gerektiğini ve etkinliklerin kapsamına ilişkin önerilerini katılımcılar vurgulamaktadır. İki kurum arasında eğitsel kültürel alanlarda işbirliği yapılarak projeler üretilmesi katılımcılar tarafından dile getirilmektedir. MEB Yurt Dışı Türk Okullarının yabancı kamuoyunu etkilemedeki potansiyelinin Türk Büyükelçilikleri tarafından göz ardı edilmemesi son derece önemlidir. Kalın (2011)'a göre karşılıklı iletişimi ve etkileşimi tasavvur eden kamu diplomasisi, hedef kitleyi dinleyerek ve öncelikleri belirleyerek çok yönlü iletişimin çekirdeğini oluşturmaktadır. Bu bağlamda dinamik ve çok boyutlu bir iletişim süreci olarak kamu diplomasisinin esas unsurları, konuşmak kadar dinlemek, açıklamak kadar anlamak, bilgilendirmek kadar diyalog kurmaktır (Kalın, 2011). Uluslararası

146|P a g e

wWw.iiste.org 
toplum ile kurulan iletişim stratejileri sadece diplomatik düzeydeki makro girişimlerle sürdürülmemeli eş zamanlı olarak gündelik ilişkiler düzeyinde mikro uygulamalara da yer verilmelidir. Uzun vadeli ilişkilerin temelini oluşturan mikro düzey ilişkiler aracıllğıyla uluslararası toplumda güvenilirlik sağlanabilmekte ve makro düzey çalışmalardan faydalanmak kolaylaşabilmektedir (Eken, 2015, s.43). Araştırmadan elde edilen bulgulardan birisi de MEB Yurt Dışı Türk Okullarında eğitim öğretim gören öğrencilerin güçlendirileceği alanlara iliş̧in bulgulardır. MEB Yurt Dışı Türk Okullarında eğitim hizmeti alan öğrencilerin güçlendirileceği alanlara ilişkin sosyal alanlar bağlamında kulüp çalışmalarının yapılması gerektiğini (2/30), bulunduğu ülkenin sosyal yaşamına uyum sağlaması gerektiğini (8/30), okul aile ilişkisinin yapılandırılması gerektiğini (1/30), Türk toplumunun birbirleri ile kaynaşması gerektiğini vurgulamaktadırlar. Katılımcılar kültürel alan bağlamında Türk Okullarındaki öğrencilerin halk oyunlarını (6/3) ve Türk el sanatlarını öğrenmesi gerektiğini (3/30) ifade etmektedirler. MEB Yurt Dış1 Türk Okullarındaki öğrencilerin sportif alana bağlı olarak milli sporlar (4/30) ve sportif etkinlikler (6/30) alanlarında güçlendirilmesinin Türk Okullarının kamu diplomasisinde yumuşak bir güç olarak etkililiğini sağlayabileceğini vurgulamaktadırlar. Öğrencilerin güçlendirilebileceği akademik alanlarla ilgili olarak katılımcılar akademik alanlardan okuma alışkanlığının kazandırılması gerektiğini (1/30), ortak derslerin öğretimini (1/30), sınırlı akademik kaynak sorununun çözümünü (2/30), Türkçe’nin öğrenimini (9/30), yabancı dilin öğrenilmesi gerektiğini (16/30), yeni müfredat gereksiniminin karşılanması gerektiğini (4/30) aktarmaktadırlar. Öğrencilerin değerler eğitimi bağlamında güçlendirilmesi de elde edilen bulgular arasındadır. Bu kapsamda yabancılaşmanın önüne geçilmesi gerektiği (1/30), milli değerlerin geliştirilmesi gerektiği (6/30), örnek kişilerin davet edilmesinin sağlanması gerektiği (3/30), Türk örf ve adetlerinin öğretilmesi gerektiği (1/30) ve Türkiye ziyaretlerinin yapılarak gönül köprülerinin inşa edilmesi gerektiği (2/30) katılımcıların görüşlerinden elde edilen bulgular arasındadır. Sezgin ve Yolcu (2016)'ya göre, göç eden topluluğun göç ettiği yerdeki toplumla etkileşimi sosyal uyumu gerektirdiğinden toplumun tüm kurumlarını etkilemektedir. Uyum sürecinde eğitim kurumlarının aktif görevleri bulunmaktadır (Sezgin ve Yolcu, 2016). Bu araştırmada öğretmenlerin hizmet içi eğitimlerden beklentileri, kurumlar arası düzeyde mesleki gelişimlerini pekiştirici uygulamaların neler olduğu konusunda elde edilen bulgulara göre hizmetiçi eğitim çalışmalarının niteliği ile ilgili öğretmen görüşlerine yer verilmiştir. Katılımcılar, yurt dışı görevdeki bir öğretmenin kurumlararası düzeyde mesleki gelişimini destekleyecek hizmetiçi eğitimler temasına yönelik konularının gerçekleşmesi gerektiğini (11/30), yurt içi eğitim seminerlerinden faydalanmaları gerektiğini (3/30), hizmetiçi eğitimlerin içeriğinin ihtiyaçlara dönük olması gerektiğini (7/30), mevcut hizmetiçi eğitimlerin uygulanamadığını (6/30), kurumlararası hizmetiçi eğitimlerin yapılması gerektiğini vurgulamaktadırlar. Bando ve Li (2014) etkili bir hizmet içi eğitim için hizmet içi eğitim programını dört koşula bağlamaktadır. Bunlar öğrenci davranışını değiştirebilmek için yetirince yoğunlaştırılmış bir program olmalıdır, uygulamalı olmalıdır, süreklilik arz etmelidir ve öğretmeni teşvik etmelidir (Bando ve Li, 2014). Araştırma sonucunda ortaya çıkan bir diğer bulgu da okul imajına yönelik öğretmenlerin görüşlerini ifade etmeleridir. Türk Okulu imajının ne düzeyde olduğu ve olumlu okul imajının sağlanabilmesi amacıyla Türk Okullarının bulundukları ülkenin dilinin öğretiminin gerektiğini (2/30), diğer okullarla işbirliği yapılması gerektiği (5/30), kaliteli okul binalarının inşa edilmesi gerektiği (14/30), kültürel değerlerin kazandırılması gerektiği (5/30), medyanın kullanılarak etkinliklerden kamuoyunun haberdar edilmesinin gerektiği (1/30), okul tanıtım faaliyetlerinin yapılması gerektiği (2/30), olumlu okul veli ilişkisinin tesis edilmesi gerektiği (1/30), öğretmenlerin gelişiminin sağlanması gerektiği (5/30), öğretmenlerin yaşam koşullarının iyileştirilmesi $(2 / 30)$, Türkçe'nin diğer okullarda seçmeli ders olarak okutulması gerektiği (1/30), Türkiye sempatisinden faydalanılması gerektiği (9/30) yönünde görüşlerini aktarmaktadırlar. Eger, Egerova ve Pisonova (2018)'e göre okul imajı, okul üyelerinin (öğrenciler, öğretmenler ve okul yönetim üyeleri, aileler ve diğer paydaşlar) bireysel etkilerinden oluşan mozaik olarak tanımlanmaktadır. Sadece öğretmenlerin anladığı şey olmayan okul imajı, okul üyelerinin zihninde var olan eğitim programı ve okula ilişkin inançlarını ve duygularını içermektedir. Okul imajını anlamak ve sürdürmek için okulun mevcut imajının ne olduğunun bilinmesi ve iç ve dış paydaşlar tarafından nasıl algılandığının bilinmesi gerekmektedir (Eger, Egerova \& Pisonova, 2018). Araştırmadan elde edilen bulgulardan birisi de MEB Yurt Dıșı Türk Okullarının denetim mekanizması bağlamında ortaya çıkan bulgulardır. Katılımcılar MEB Yurt Dışı Türk Okullarında yürütülen eğitim denetim mekanizmalarının işleyişi hakkındaki görüşlerini ifade ederken aynı zamanda etkili eğitim denetim mekanizmalarına ilişkin önerilerini de dile getirmektedirler. Bu kapsamda katılımcılar, bulundukları ülkenin yerel makamlarınca denetim yapıldığını (1/30), çok yönlü performans değerlendirme yapılmasının gerektiğıini $(9 / 30)$, deneyim paylaşımlarının önemli olduğunu (1/30), eğitim ataşelerinin denetim görevinin olduğunu (1/30), etkin

147|P a g e

www.iiste.org 
denetim sistemi ihtiyacının var olduğunu (7/30), merkezden ziyaretlerin yapılması gerektiğini (2/30), denetim mekanizmalarında mevzuat boşluğu olduğunu (3/30), okul müdürünün merkezden görevlendirilmesi gerektiği (2/30), okula dayalı yönetim sisteminin yapılandırılması gerektiği (8/30) ve denetim süreçlerinde rehberlik desteğinin verilmesi gerektiği yönünde görüşlerini ifade etmektedirler. Eğitimde yüksek kaliteli değerlendirme sistemleri hem bireysel ilerleme hem de örgütsel etkililik için çok önemlidir (Stronge, 1991). Akşit (2006)'in çalışmasına göre öğretmenler, performans değerlendirmenin hedeflerini anlamadığını ve performans değerlendirmenin bu hedefleri sağlamadığını düşündükleri ortaya konmuştur (Akşit, 2006). Akyel ve Köse (2010)'ye göre, süreçlere, yöntemlere ve kurallara bağlı kalarak yönetimi tanımlayan klasik yönetime karşı, işletme yönetimi hedeflere, önceliklere, uygulama planlarına, etkin insan kaynağına, performans değerlendirmeye ve hesap verebilirliğe bağlı olarak işlemektedir (Akyel ve Köse, 2010). Etkinlik, kurumun amaçlarına ve stratejik hedeflerine ulaşmak amacıyla yapılan faaliyetler sonucunda, amaçlara ne derece ulaşıldığını gösteren bir performans boyutudur (Arslan, 2002). Araştırmadan elde edilen bir diğer bulgu da yasal düzenlemelere bağlı olarak ortaya çıkan bulgulardır. MEB Yurt Dişı Türk Okullarında görevli personel Bakanlıklar arası Ortak Kültür Komisyonunun Çalışma Esas ve Usulleri ile $\mathrm{Bu}$ Komisyon Tarafından Yurt Dışında Görevlendirilecek Personelin Nitelikleri ile Hak ve Yükümlülüklerinin Belirlenmesine İlişkin Karar’a bağlı olarak çalışmaktadır. Bu Kararla, Türk kültürünün yurtdışında tanıtılması, yayılması ve korunması, yurtdışındaki vatandaşlarımız ve soydaşlarımızın kültürel bağlarının korunması, güçlendirilmesi ve dini konularda aydınlatılması ile Türk dilinin öğretilmesi amacıyla yurtdışına görevlendirilecek personelin unvanı, sayısı, nitelikleri, seçimleri, görev yerleri ve süreleri, izinleri, yurtdışındaki görevlerinin sona erdirilmesi ve diğer hususlara ilişskin esas ve usuller düzenlenmiştir. araştırmaya katılan katılımcılar, MEB Yurt Dışı Türk Okullarının bağlı olduğu mevzuatların düzenlenmesine ilişkin görüşlerini aktarmaktadırlar. Yasal düzenlemeler kapsamında bölgesel çözümlerin belirlenmesi gerektiği (7/30), destekleme ve yetiştirme kurslarının yurt dışında da uygulanabilmesi gerektiği (2/30), eokul yönetim bilgi sisteminin Yurt Dışı Türk Okulları için yeniden oluşturulması gerektiği (1/30), ilgili yönetmeliklerin güncellenmesi gerektiği (14/30), izin günlerinin düzenlenmesi gerektiği (13/30), yurt içi ve yurt dişı maaşlarının birleştirilmesi gerektiği (2/30), okul servislerinin yasal işletilmesi gerektiği (1/30), oturum vergisinin alınması ile ilgili olarak yaşanan sorunların giderilmesi gerektiği (3/30), öğretmenlerin görevlendirilmesindeki ölçütlerin yeniden yapılandırılması gerektiği (1/30), sağlı ödemelerinin yapılandırılması gerektiği (14/30), ulaşım giderlerinin karşılanması gerektiği (1/30) yönünde katılımcılar görüşlerini ifade etmektedirler.

$\mathrm{Bu}$ araştırmanın bulguları MEB Yurt Dışı Türk Okullarının kamu diplomasisinde etkili bir aktör olarak çok yönlü işbirliği ile mevcut sorunlara 1şık tutmakta ve bu bağlamda uygulayıcılara ve araştırmacılara öneriler sunmaktadır. MEB Yurt Dışı yapılanmasının daha etkin bir yapıya kavuşturulması, yurtdışında yaşayan vatandaşlar ve kardeş topluluklar ile ekonomik, sosyal ve kültürel olarak yakın ilişkiler tesis edilmesinin sağlanmasına yönelik bulgular ortaya çıkmıştır. Bu bağlamda Türk Okulları üzerinden kurulması gereken koordinasyon çalışmalarının gerek kamu diplomasisini daha etkin kılmak gerekse Türk diasporasının potansiyel gücünden istifade edebilmesi amacıyla çözüm stratejilerinin elde edilen bulgular temelinde üretilmesi sağlanabilir.

\section{Kaynakça}

Akşit, F. (2006). Performans değerlendirmeye ilişkin öğretmen görüşleri (Bigadiç ilköğretim öğretmenleri örneği). Sosyal Bilimler Araştırmaları Dergisi, 1(2), 76-101.

Akyel, R. ve Köse, H. Ö. (2010). Kamu yönetiminde etkinlik arayışı: Etkin kamu yönetimi için etkin denetimin gerekliliği. Türk İdare Dergisi, 466, 9-45.

Arslan, A. (2002). Kamu harcamalarında verimlilik, etkinlik ve denetim. Maliye Dergisi, 140(2), 1-14.

Bando Grana, R. ve Li, X. (2014). The effect of in-service teacher training on student learning of English as a second language (No. IDB-WP-529). IDB Working Paper Series.

Biernacki, P. ve Waldorf, D. (1981). Snowball sampling: Problems and techniques of chain referral sampling. Sociological Methods \& Research, 10(2), 141-163.

$\mathbf{1 4 8} \mid \mathrm{P}$ a g e

www.iiste.org 
International Journal of Scientific and Technological Research

ISSN 2422-8702 (Online), DOI: 10.7176/JSTR/6-06-10

Special Issue of Educational Sciences, Vol.6, No.6, 2020

Büyükgöze, H. (2016). Bir etki aracı olarak Türk yükseköğretiminin 'yumuşak güç' bağlamında incelenmesi. Journal of Higher Education \& Science/Yüksekögretim ve Bilim Dergisi, 6(1).

DiCicco-Bloom, B. ve Crabtree, B. F. (2006). The qualitative research interview. Medical education, 40(4), 314-321.

Eger, L., Egerova, D., Pisonova, M. (2018), Assesment of school image. Center for Educational Policy Studies Journal, 8(2), 97-122.

Eken, M. E. (2015). Jeopolitik derinlik, akılcı güç ve popüler kültür: Stratejik bir konsept olarak gündelik hayatın önemi. Şahin, M., Çevik, B. S. (Ed.), Türk dış politikası ve kamu diplomasisi, ss. 17-44, Ankara: Nobel Yayıncılık.

Fan, Y. (2010). Branding the nation: Towards a better understanding. Place branding and public diplomacy, 6(2), 97-103.

Guba, E. G. ve Lincoln, Y. S. (1982). Epistemological and methodological bases of naturalistic inquiry. ECTJ, 30(4), 233-252.

Hayden, C. (2012). The rhetoric of soft power: Public diplomacy in global contexts. UK: Lexington Books,

https://www.britishcouncil.org/organisation/facts/what-the-british-council-does/contribution-uk-softpower, (1 Aralık 2017).

https://www.sb.k12.tr/dayanisma/yardim-calismalari/ Saint Benoit Lisesi, (13 Kasım 2017).

https://www.goethe.de/ins/tr/tr/ueb.html (21 Aralık.2017).

https://ci.metu.edu.tr/tr/amaclarimiz (2 Kasım 2018).

Ipe, M. (2003). Knowledge sharing in organizations: a conceptual framework. Human Resource Development Review, 2(4), 337-59.

İnand1, Y., Yeşil, H., Karatepe, R. ve Uzun, A. (2015). Öğretmenlerin ve okul müdürlerinin özyeterlikleri ile değişime gösterdikleri direnç arasındaki ilişkinin incelenmesi. Mersin Üniversitesi Ĕ̌itim Fakültesi Dergisi, 11(2).

Kalın, İ. (2011). Soft power and public diplomacy in Turkey. Perceptions, 16(3), 5.

Krefting, L. (1991). Rigor in qualitative research: The assessment of trustworthiness. American journal of occupational therapy, 45(3), 214-222.

Krippendorff, K. (2004). Content analysis: An introduction to its methodology. UK: Sage Publications, Inc.

Louise Barriball, K. ve While, A. (1994). Collecting Data using a semi-structured interview: Adiscussion paper. Journal of Advanced Nursing, 19(2), 328-335.

Marczyk, G., DeMatteo, D., \& Festinger, D. (2017). Essentials of research design and methodology, NJ: John Wiley. 
International Journal of Scientific and Technological Research

ISSN 2422-8702 (Online), DOI: 10.7176/JSTR/6-06-10

Special Issue of Educational Sciences, Vol.6, No.6, 2020

McClory, J. (2015). The soft power 30: A global ranking of soft power. Portland: Portland Communication. http://comresglobal.com/wp-content/uploads/2015/07/Report_Final-published. (11 Mart 2018).

Merriam, S. B. ve Tisdell, E. J. (2016). Qualitative research: A guide to design and implementation. (4th. Edition).CA: John Wiley \& Son.

Nye Jr, J. S. (2004). Power in the global information age: From realism to globalization. NY: Routledge.

Nye Jr., J. S. (2017). Yumuşak güç: Dünya siyasetinde başarının araçları, İnan Aydın, R. (çv.), Ankara: BB101 Yayınlar1.

Özkan, A. (2015). Strategic practices of public diplomacy policies in educational field and Turkey's potential for cultural diplomacy. Procedia-Social and Behavioral Sciences, 176, 35-43.

Pamment, J. (2012). What became of the new public diplomacy? Recent developments in British, US and Swedish public diplomacy policy and evaluation methods. The Hague Journal of Diplomacy, $7(3), 313-336$.

Polglase, G. (2013). Higher education as soft power in the Eastern Partnership: the case of Belarus. Eastern Journal of European Studies, 4(2).

Sezgin, A. A. ve Yolcu, T. (2016). Göç ile gelen uluslararası öğrencilerin sosyal uyum ve toplumsal kabul süreci. Humanitas, 4(7), 417-436.

Stronge, J. H. (1991). The dynamics of effective performance evaluation systems in education: Conceptual, human relations, and technical domains. Journal of Personnel Evaluation in Education, 5(1), 77-83.

Şimşek, H., \& Yıldırım, A. (2011). Sosyal bilimlerde nitel araştırma yöntemleri. Ankara: Seçkin Yayıncilik.

Trilokekar, R. D. (2010). International education as soft power? The contributions and challenges of Canadian foreign policy to the internationalization of higher education. Higher Education, 59(2), 131-147.

Ünal Erzen, M. (2014). Kamu diplomasisi. İstanbul: Derin Yayınları.

Vial, V. ve Hanoteau, J. (2019). The sustained incremental multi-actor multi-action building of South Korean soft power in Indonesia. The Pacific Review, 32(1), 56-75.

Yıldırım, A., Şimek, B. (2006). Sosyal bilimlerde nitel araştırma yöntemleri. (5. Baskı) Ankara: Seçkin Yayıncilik. 